\title{
State Phobia in Foucault readings
}

DEAN, M.; VILLADSEN, K.

State phobia and civil society: the political legacy of Michel Foucault.

Stanford, California: Stanford University Press, 2016

\author{
$I^{1}$ Henrique Sater de Andrade I \\ 1 Universidade Estadual de Campinas. Campinas-SP, Brasil (hsatera@gmail.com). ORCID: 0000-0001-9847-3663 \\ Recebido em: 11/03/2020 \\ Aprovado em: 25/07/2020 \\ Revisado em: 09/10/2020
}

DOI: http://dx.doi.org/10.1590/S0103-73312020300421

The discussion around the State seems to have entered a kind of prohibited zone for the Foucauldian perspective, and post-structuralism more broadly. Instead of investigating its structure, functions and components, researchers from diverse backgrounds have been seeking in recent decades to analyze society beyond the state, decentralizing and displacing its existence.

It is an intellectual stance inspired especially by the reflections on "governmentality" made by Michel Foucault in the 70s and that refuses to take the state as a unified center of control controlled by certain social classes. In another direction, it tries to analyze the heterogeneity of government practices, programs and rationalities in their multiple alliances and actors, including the public sector, community organizations, corporations, and the citizens themselves. Undoubtedly, these analyzes have improved our critical understandings over the exercise of political power and new arrangements of public institutions and policies that have been increasingly permeated by a neoliberal rationality of government. Would they not, on the other hand, have gone too far in abandoning the form of the state in their contemporary political and social analyzes? 
This is the question that gives rise to the book "State Phobia and Civil Society: the political legacy of Michel Foucault" (Stanford University Press, 2016) by Mitchell Dean and Kaspar Villadsen, both professors at Copenhagen Business School. Starting from the concept of "statephobia", used by Foucault himself to criticize and warn against political theories that exaggerated the negative role of the State in society and human history, the study extensively recovers courses, interviews and other extracts that address the problem of state and civil society.

The authors make it clear that they do not agree with those who consider civil society at first as a privileged locus of anti-governmental counter-conduct and resistance practices or as a sphere of virtue and instructive solutions to human problems. Nor do they view a civil society capable of replacing an inefficient, costly, and inept state in a more creative, flexible, and ethical way. They do not bet or show enthusiasm for a possible dissolution of the state, in a progressive merger with the civil society.

The work is particularly relevant in a global context in which governments try to reduce the role of the state in the provision of public services, encouraging local communities, non-governmental organizations, private corporations, and other civil society actors to perform such functions. Especially for the field of Brazilian Public / Collective Health, which has been critically debating the multiple attacks against our Public Health System (SUS) in recent years. Concomitantly to these changes, social and political scientists have adopted a skeptical view of the state, characterizing it as something increasingly empty, superfluous, and devoid of sovereignty. In its place, new mobile government networks, transnational, fluid and immaterial, would be gradually appearing, producing a "governance without government" and a kind of "stateless state".

It is worth mentioning that, even if momentarily, the covid-19 pandemic is playing a relevant role in pushing a large part of the planet to re-discuss the importance of the state and the need for its expansion, especially in the provision of public health services and income transfer programs.

The authors also draw attention to the fact that this skepticism has been influencing political groups that oppose the positions historically taken by a traditional Left in defense of universal rights and public policies. As Dean and Villadsen provoke us:

How did the "young Foucauldians" come to adopt such "state-phobic" positions, which involved their going to great lengths to avoid dealing with the state's role, analytically as 
well as normatively? Down which long and winding theoretical roads did they meander to reach an explicit or implicit negative position on the state, and what are the political consequences of this today? (p. 5)

\section{Relations between the state and civil society}

The first three chapters of the book trace back the uses of the concept of "civil society" in the work of Michel Foucault and of different intellectuals who dialogue with him. In the course "The Birth of Biopolitics", from 1979, Foucault understands the civil society is related to the art of liberal government and the emergence of the economic subject within society. It is this homo oeconomicus that will inhabit the reality of civil society.

Thus, the analysis connects the formation of civil society to the government technologies that shaped and constituted the state itself, in a process that he named as a "governmentalization of the state". Therefore, there is in this reading a juxtaposition between the state and civil society. Without taking them as universal and already given concepts, Foucault permanently questions the discursive grids and rationalities of government that made the state's emergence possible. The state appears as something perpetually modified, which exists, but never sufficiently.

This methodological option for an analysis of governmental rationalities will influence a group of Anglo-Saxon researchers, responsible for the so-called "governmentality studies" from the 1990s. This group originally included Mitchell Dean, one of the authors of the book reviewed here, and an important reference for the studies of methodology and governmentality in Foucault's work.

These studies aimed to overcome the binary separation between state and civil society, considering it as a kind of analytical "dead end" that prevent us from understanding the complexity of the forms of government exercise practiced locally and globally. Nikolas Rose and Peter Miller, for example, tacitly claim that the language that conceptually separates the state and civil society is no longer capable of understanding the transformations in contemporary ways of exercising political power.

This type of statement would justify the theoretical shift of these researches from macro-political concerns - such as the structure of social classes, the concentration of power and wealth and the role of state intervention and regulation -, to "local", "diffuse" and "minor" government practices, inserted in a micropolitical plan for 
the exercise of power. A kind of turn to a localized study of discourses, subjectivity technologies and micropolitics and microphysics of power.

Dean and Villadsen point out in the book that the Foucauldian method of decentralizing the state involved precisely the opposite movement. When observing the psychiatry, the prison system, the hospital medicine and the justice, Foucault has always taken the state itself as an object of investigation. His interest was to unveil the modern state's own experience and genealogy through the analysis of these different dispositifs. The very idea of "governmentality" appears textually in Foucault's work as an analysis of the state, not as something outside or beyond it.

Therefore, this "governmentality" investigation would reveal the conditions for the existence, expansion and the experience of a state ceaselessly confronted with its external domain that is civil society. It is in this confrontation that the exercise of government takes place and must be observed. The authors remember us that the reflections on governmentality are all transcripts of oral courses. Without Foucault's final review, they should be considered from its performance and provocative dimension and related to specific events in France at the time. Thus, they suggest that we should consider the statements related to the State and civil society in the very context in which they were enunciated. Some in an exegetical and methodological character, others directed to a variety of interlocutors, seeking to analyze and intervene on historical facts. The governmentality courses involved a direct and implicit dialogue with the Marxist theories of the state and with the crisis of institutional socialism, in tension with liberal democracies. Also, with different currents of the French political Left, which believed less or more on the role of control and state intervention.

In the late 1970s, rejecting the theory of the state meant rejecting the Marxist theory of the state and marking kind of a position in favor of anti-institutional movements present both in liberal democracies and those who opposed state socialism. Opening the debate on "local struggles" meant a kind of break with the intellectual problem of the predominant left and an attempt to open up the discussion between government and state.

The book points out that the dissolution of the concept of state made by governmentality studies from the end of the 20th century ended up having the opposite effect. They reinforced a "kind of anti-political orthodoxy that made the Left a meaningless term” (p. 19). And signifying, in a sense, an adherence to 
the political agenda of neoliberalism, a movement that Foucault was one of its precursor analysts.

\section{Risks of the "multitude" metaphysics and a stateless "ethico-politics"}

Based on the conceptual retrospect of civil society and the state, Dean and Villadsen critically analyze two different readings derived from Foucault's work: the theory of the Empire and the multitude made by Michael Hardt and Antonio Negri and the governmental diagnosis of advanced liberalism and "ethico-politics" of Nikolas Rose and his colleagues.

Also inspired by Marx and Deleuze, Hardt and Negri take "postmodern and globalized" capitalism and their production of "hybrid and fragmentary" subjectivities as their object of investigation. They seek to break with a political theory centered on the nation-state and create the concept of Empire as an immanent "society of control", with the dissolution of the capital's disciplinary frontiers.

Subjectivity forms previously shaped by disciplinary institutions would escape institutional barriers. With the dismantling of the old dialectic between labor power and capital, the very conditions of civil society's existence would have "withered away". Hence, the concept of multitude, which would exceed the structures of control and domination of globalized capitalism through its energies, creativity, and learning.

The reinterpretation of the Foucauldian concept of biopolitics appears here as central to the power of the multitude, not only as a power over life, but a power of life itself, which guarantees its permanent productivity and capacity for invention. Biopolitics simultaneously as production and reproduction: a new form of power that escapes disciplinary institutions and bears the very forces of resistance that spring from within the multitude.

The book highlights how this type of conceptual inflection loses contact with the Foucauldian framework and ends up drifting towards a kind of vitalistic metaphysics of life. The fact that globalized capitalism depends on the very life of the multitude will become its fundamental and sufficient condition for it to be able to revolt and resist through the micropolitics, even if in a dispersed and uncoordinated way. In this way, the multitude would not need welfare state, workers unions, political parties, or formal associations to exercise real actions of transformation. 
Hardt and Negri, in stating that the multitude has no interest in taking control of the state apparatus, not even to direct it to other ends, would end up adopting a deeply anti-state and anti-institutional position. The state appears "a kingdom of nonfreedom", of "the seat of domination", of "capitalist exploitation" and the guarantee of hierarchical and oppressive identity policies. The multitude seeks to include and maintain the difference, instead of dissolving it in the "mindless indifference of the mass" or in the "fabricated unity of the people", but this distinction remains "a purely theoretical set of distinctions" (p. 30).

Dean and Villadsen see in this theoretical framework a kind of postmodern paradigm where the difference could express itself freely, but in a centrally aesthetic way. They question whether thinking of the multitude as a political innovation could not just mean an overwhelming limitation of our political choices. And the authors go further: could this logic of a biopolitical immanent of the multitude - self-organized and self-governing and progressively deprived of state sovereignty - not mean the very realization of the original biopower project? In this type of extrapolation, Foucault's work would end up becoming no longer a diagnostic and critical reading of the present, but merely the messenger of a great immanent and metaphysical biopolitics era.

The book also describes and investigates the school of governmentality and, in particular, the work of the British social scientist Nikolas Rose. Rose highlights the emergence of new forms of government around multiple communities and seeks an empirical rather than theoretical analysis of local and minor practices and resistance. In his analyzes, liberal forms of government continually incorporate criticism and resistance to government, in a state of perpetual mobile invention of new rationalities and practices.

According to Dean and Villadsen, Rose's perspective involves the reversibility of political power and an "anti-state-centered" approach since the advanced liberal democratic states no longer have an exercise of power comprehensible in the language and binary logic of political science. This perspective aligns state agencies with multiple non-state actors, making distinctions between state-civil society, publicprivate, government-market, and so on, obsolete. Political power would be exercised in this profusion of alliances between different authorities who seek to govern economic and social life and human conduct. The initial methodological refusal to take the 
state as the center of analysis turns out to transform itself into a theoretical structure considered more adequate to understand our contemporary forms of political power.

Besides, a considerable recognition of the potentials of this permanent social experimentation is pointed out. Away from the discourse of cohesion and state strategies, individuals would be able to finally access a variety of subjectivity techniques to invent themselves and become new types of political actors. Rose will designate this creative field of contestation and self-invention that arises with the social welfare crisis and the advanced liberalism emergence as "ethico-politics".

Dean and Villadsen draw attention to the fact that this type of approach is related to postmodern discourses on cultural diversity and societal differentiation, on the one hand, and to neoliberal strategies to dismantle and transform social assistance services and crystallize inequalities, from another. They point out the risk of this type of theory fetishizing the localized and the empirical when assuming as a rule the methodological commitment to analyze power exclusively in its particular forms. Thus, what could be a prominent method for public policy analysis, the state and society, begins to become its complete replacement. How to think about the "invention" of subjectivities, without eluding the state's role in society, for instance, involving the guarantee of standards of universal access to health and education? By neglecting access and equality features, the "ethico-politics" becomes the preservation of a privileged caste, on a national or global scale, in its vitalist, consumerist, technological and lifestyle elements.

In later works, Rose will move from stricto sensu political analysis to analyzes of neuroscience, genomics, and psychiatry and to investigations of understating "ourselves". The book claims that this displacement holds, like Hardt and Negri, a certain fascination with the "bio", grasping the brain as a plastic and open device for subjectivity development. It is clear here the evocation of a certain vitalism and a pursuit of politics that encompasses the life and the living, energy, creativity, vitality, and nomadism, based on Deleuze thoughts.

Biopolitics is central both in the "messianic narrative" (p. 42) of the Hardt and Negri multitude and in the "meticulous empirical approach" (p. 42) of Rose's ethicopolitics and advanced liberalism. They object to dissolve the traditional binomial state-civil society, claiming a political power beyond the state. A world with little rigidity and no structure, distrustful of formal institutions and a nomadic, mobile, and fluid policy. 
Despite being advertised as radically distinct intellectual projects, Dean and Villadsen finalize these initial chapters demonstrating that there are more similarities than differences between Hardt and Negri's work with that of social scientists from the school of governmentality like Nikolas Rose.

\section{"Saint Foucault" in defense of subjugated knowledge and oppressed groups}

Foucault is commonly described as an activist of his time. His name appears linked to the struggles against the asylum, medicalization of life, mass incarceration and issues linked to freedom and sexual diversity. He is represented as a theorist of resistance and new forms of struggle, located outside the conventional domain of politics and the state, and placed in that of civil society.

It is this image that the fourth chapter of the book calls a "Saint Foucault", present in the work of David Halperin, an American intellectual who studied the gay culture of the United States in the 1970s, when Foucault lived there. In this passage, Dean and Villadsen raise a suspicion regarding theoretical approaches that seek in Foucault a kind of political, intellectual, and moral guide to the politics of difference and the struggles of social movements.

The authors acknowledge that the philosopher has stated on several occasions his anti-institutional orientation and that he preferred to side with the oppressed, rather than representing them as a spokesman who defended them. They show their interest on historically marginalized, disqualified, and subjugated knowledge. Several passages in Foucault's work emphasize the dispersed and the informal before the unitary and formal - and give up a common and universal theoretical regime that seeks a validity of thought. His thinking pursues a rupture with the tyranny of a unitary theoretical and scientific discourse.

However, the authors also present Foucault's reservations about civil society itself. In analyzing lettres de cachet, prison orders issued with a royal seal between the 17th and 18th century, Foucault described petitions presented by ordinary people who wished to see severe punishments for some minor conduct. In these letters, the king's power was revealed to be integrated with an immanent micropower: requests for imprisonment were presented by humble illiterates and in a comical and absurd language that was deemed necessary for the wishes of punishment to be fulfilled. 
Sovereign power was not, therefore, sustained exclusively by a central authority, but it was produced by the subjects themselves governed by their most intimate relations. The punishment reached those who were already victims of marginalization by their own social group: a kind of violence secondary to the very exclusions present in civil society. Civil society appears in a gloomy and contradictory way; in contrast to a certain optimism seen in recent Foucauldian literature.

\section{Limits of virtuality and immanence in the analysis of the state}

Chapters 5, 6 and 7 deal with the denial of a universal state in Foucault's work. Taking an important course in 1976 ("Society Must Be Defended"), they show how the French philosopher takes war and conflict as drivers of politics and social body's own existence, contrary to the apparent naturalness and functional need attributed to the state institutions and laws. In contrast to such universality, there is a progressive decentralization of the state analysis from its multiple dispositifs. The imaginary solidity of state apparatus is dissolved in an immanent universe and could no longer be distinguished from government regimes that traverse it. The state becomes nothing more than the fragile and transitory effect of various governmentalities. In this immanent plane, the dispositifs themselves define the nature of problems that they are concerned and produce the practices and discourses of the social body.

Dean and Villadsen recognize that the methodological use of dispositifs can help us carry out more sophisticated analyzes of politics and regulation and government, by temporarily suspending a functional and totalizing comprehension of the state and making its government rationalities intelligible. But the authors declare that this perpetual decentralization aspects, like the a priori privilege of the molecular over the molar and the multiplicity over the unity; they become eventually placing the dispositifs in "a great Heraclitean flow and flux of immanence" (p. 103).

What happens to institutions when they become an unstable and contingent plane of immanence? Dean and Villadsen dodge a question by engaging in an extensive dialogue with Deleuze's work. They argue that this immanent and permanent creative force can ironically inhibit our involvement with the constraints of the real world; likewise, they provoke us on whether this perspective does not systematically occlude our main problems when analyzing the state. 
Power centralization in a determined territory and by a group of institutions turn out to be disappearing from the perspective of the dispositifs, diagrams and practices, even preventing the application of the law and the execution of sovereignty. In other words, the very definition of the concept of the state as a form of political innovation disappears, and politics is in danger of being transformed merely into a virtual game between various technical rationalities.

\section{Redeemer civil society and Foucault's controversial apology for neoliberalism}

Chapters 8 and 9 deepen Foucault's skepticism towards civil society which is seen by him as the possibility of an apocalyptic and redeeming end of history (an eschatology). These chapters also address how secularization has progressively confused political theology with economic theology. The authors display how civil society becomes the environment in which the relative claims of the legal subject of rights and the economic subject of interests can be managed and resolved. On the other hand, in addition to a kind of empirical entity that maintains a complex relationship with the mundane order of men and things, civil society also assumes an eschatological tradition in which political movements always head towards final salvation and fulfillment, reaching the purposes of our existence.

They also argue that Foucault's governmental and economic analysis adopts a critical ethos that finds in liberalism a kind of realization of self-government and a government rationality structured from the governed subjects themselves. Not only absolute eschatology, final apocalypse, but relative eschatology. Not eternal peace, but perpetual contestation and "agonism". It turns out to be a political and economic theology that Foucault himself denies, but whose critical intellectual tradition he is heir to.

Finally, the last chapter presents a controversial view of the relationship between the French philosopher and neoliberalism. Unlike most Foucauldian intellectuals, Dean and Villadsen point to a kind apology for neoliberalism made by Foucault, especially for American's human capital theory. They do not simplistically claim that Foucault "became neoliberal", but they draw attention to his defense of power games with the least possible domination and his recurring criticisms of security welfare state dispositifs. It is also point out that Foucault's reflections on neoliberalism took him to his work's final phase that sees self-care as a practice of freedom. 
In short, the book reviewed here makes a dense and provocative reading of the work of one of the most important thinkers of the 20th century. In opposition to the anti-state currents of thought linked to Foucault, it defends both the analysis and the strengthening of the state in a neoliberal context. In addition to being something we must oppose to, the book also sees the state as "a condition of the order and security, and the development of individual and collective capacities" (p.19). However, it is worth questioning which state Dean and Villadsen refer to: whether that of Denmark, the country in which they reside, or that of a country such as Brazil.

Reading their reflections ends up leading us to a difficult paradox. On the one hand, the defense of the strengthening of public policies, fundamental to the social and human development of any nation, especially in the current world context of the pandemic. On the other hand, the understanding of the state's repressive role, source of inequalities and holder of the power of violence and death, especially in the Brazilian case.

Undoubtedly, this book is an indispensable reading for those who seek to make social and political analyzes in dialogue with Foucault and are suspicious of the state phobia of different post-structuralist thinkers who are inspired by his work.

\section{Reference}

DEAN, M.; VILLADSEN, K. State phobia and civil society: the political legacy of Michel Foucault. Stanford, California: Stanford University Press, 2016.

\section{Note}

${ }^{1}$ The debate about the "stateless state" has had a strong presence in Anglo-Saxon political thought, both linked to post-structuralism of authors like Barry Hindess (who published a book in the 1990s with Mitchell Dean, one of the authors of the book reviewed here), Alan Finlayson, James Martin and to contemporary governance discussed by Mark Bevir and Roderick William Rhode. 